\title{
PELAKSANAAN PEMBELAJARAN PENDIDIKAN JASMANI ADAPTIF BAGI ANAK DENGAN HAMBATAN FISIK DAN MOTORIK
}

\author{
Johandri Taufan' ${ }^{1}$, Ardisal $^{2}$, Damri $^{3}$, Arise $^{4}$ \\ ${ }^{1234}$ Universitas Negeri Padang, Indonesia, \\ Email: johandri.taufan@fip.unp.ac.id
}

\section{INFORMASI ARTIKEL}

Terkirim 31 Oktober 2018

Revisi 12 November 2018

Diterima 15 November 2018

Kata kunci:

Jasmani Adaptif, Hambatan Fisik dan

Motorik.

\begin{abstract}
ABSTRAK
This research to describe the implementation of adaptive sports education for physical and motoric $X$ disability students in SDN X. This Research use descriptive qualitative method. Data collecting technique used in form of observation, interview and documentation study. Research subject are physical and motoric $X$ disability students and teacher sports education initially called Z. Result of research indicated that school there is no special treatment in making learning program design, but in its implementation there are some different activities which will be given to physical and motoric $X$ disability students without diminishing the meaning and purpose of its learning.
\end{abstract}

\section{Pendahuluan}

Pendidikan jasmani pada hakikatnya adalah proses pendidikan yang memanfaatkan aktivitas fisik untuk menghasilkan perubahan holistik dalam kualitas individu, baik dalam hal fisik, mental, serta emosional. Pendidikan jasmani seharusnya memperlakukan anak sebagai sebuah kesatuan utuh, mahluk total, tidak hanya menganggap sebagai seseorang yang terpisah kualitas fisik dan mentalnya. Pada dasarnya pendidikan jasmani, dengan memanfaatkan alat gerak manusia, dapat membuat aspek mental dan moral pun ikut berkembang. .

Fokus pendidikan jasmani pada pengaruh perkembangan fisik terhadap wilayah pertumbuhan dan perkembangan aspek lain dari manusia itulah yang menjadikan unik. Tidak ada bidang tunggal lainnya seperti pendidikan jasmani yang berkaitan dengan perkembangan total manusia. Pada dasarnya pendidikan jasmani, dengan memanfaatkan alat gerak manusia, dapat membuat aspek mental dan moral pun ikut berkembang. Dalam konteks pendidikan inklusif, pelayanan pendidikan jasmani diberikan kepada semua anak dengan karakteristik yang berbeda - beda termasuk Anak Berkebutuhan Khusus (ABK). Di sekolah yang menyelenggarakan pendidikan inklusif terdapat peserta didik yang mengalami beranekaragam hambatan, baik hambatan penglihatan, pendengaran, motorik, komunikasi, perhatian, emosi, perilaku, sosial, dan sebagainya.

Mereka berhak atas pendidikan jasmani yang dapat mengakomodasi hambatan dan kebutuhan yang mereka miliki. Oleh karena itu, pembelajaran pendidikan jasmani menjadi lebih kompleks bagi guru pendidikan jasmani dalam mengupayakan agar semua kebutuhan anak akan gerak dapat terpenuhi dan dapat meningkatkan potensi yang dimilikinya secara optimal. Pada kenyataannya tidak semua ABK mendapatkan layanan pendidikan jasmani sesuai dengan kebutuhan atau hambatan yang dimilikinya, karena tidak semua guru pendidikan jasmani memahami dan mengetahui layanan yang harus diberikan kepada ABK.

Kebutuhan gerak ABK lebih besar daripada siswa lainnya, karena ABK mengalami hambatan dalam merespon rangsangan yang diberikan lingkungan untuk melakukan gerak, meniru gerak dan bahkan ada yang memang fisiknya terganggu sehingga ia tidak dapat melakukan gerakan yang terarah dengan benar Hal ini terjadi karena mereka memiliki masalah dalam sensorisnya, motoriknya, belajarnya, dan tingkah lakunya yang dapat menghambat perkembangan fisik siswa tersebut. Seperti yang di ungkapkan oleh Irham Hosni (2003) bahwa: Anak berkebutuhan khusus memiliki masalah dalam sensorisnya, motoriknya, belajarnya, dan tingkah lakunya. Semua ini mengakibatkan terganggunya perkembangan fisik anak. Hal ini karena sebagian besar ABK mengalami hambatan dalam merespon rangsangan yang diberikan lingkungan untuk melakukan gerak, meniru gerak dan bahkan ada yang memang fisiknya terganggu sehingga ia tidak dapat melakukan gerakan 
yang terarah dengan benar. Mereka tetap sangat membutuhkan layanan pendidikan jasmani, oleh karena itu di butuhkan bentuk pendidikan jasmani yang dapat mengakomodasi setiap individu sesuai dengan keunikannya masing-masing. Pendidikan jasmani seperti itu disebut dengan pendidikan jasmani adaptif.

Demikian juga halnya pada anak gangguan fisik dan motorik dimana secara umum gangguan fisik dan motorik merupakan ketidakmampuan anggota tubuh untuk melaksanakan fungsinya disebabkan oleh berkurangnya kemampuan anggota tubuh untuk melaksanakan fungsi secara normal, akibat luka, penyakit atau pertumbuhan tidak sempurna sehingga untuk kepentingan pembelajaran perlu layanan khusus, Suroyo (dalam Karyana dan Widiati 2013: 32).

Pendidikan jasmani adaptif adalah suatu proses mendidik melalui aktivitas gerak untuk laju pertumbuhan dan perkembangan baik fisik maupun psikis dalam rangka pengoptimalan seluruh potensi kemampuan, keterampilan jasmani yang disesuaikan dengan kemampuan dan keterbatasan anak, kecerdasan , kesegaran jasmani, sosial, kultural, emosional, dan rasa keindahan demi tercapainya tujuan pendidikan yaitu terbentuknya manusia seutuhnya. Dari beberapa definisi di atas menggambarkan bahwa pendidikan jasmani adaptif adalah suatu program pembelajaran dalam memenuhi kebutuhan psikomotor anak yang dirancang sedemikian rupa sesuai dengan keunikan anak tersebut.

Berdasarkan grandtour yang penulis lakukan di SDN X Penyelenggara Pendidikan Inklusif, penulis melihat sekolah yang didesain berbentuk leter $U$ ini memiliki lapangan upacara yang cukup luas sekaligus di jadikan sebagai tempat berolahraga bagi siswa setiap harinya. di SDN X tersebut. Terdapat 1 (satu) orang anak dengan hambatan fisik dan motorik yang duduk di bangku kelas V. Anak ini termasuk anak yang pintar dan aktif dikelasnya. Tidak ada hambatan yang berarti baginya dalam mengikuti pembelajaran di kelas secara akademik namun dalam pembelajaran pendidikan jasmani olahraga dan kesehatan merupakan mata pelajaran yang membutuhkan kegiatan fisik maka penulis berasumsi akan ada modifikasi dalam mata pelajaran ini. Berdasarkan fakta diatas, mendorong penulis untuk mendalaminya. Penulis ingin mengetahui bagaimanakah pelaksanaan pembelajaran pendidikan jasmani adaptif bagi anak hambatan fisik dan motorik (X) di SD X Kecamatan Pauh.

\section{Metode}

Jenis penelitian yang dipergunakan yaitu penelitian deskriptif kualitatif. Menurut Arikunto (2006:121) "penelitian deskriptif tidak dimasukkan untuk menguji hipotesis tertentu, tetapi hanya menggambarkan "apa adanya" tentang suatu variabel, gejala atau keadaan". Sejalan dengan hal tersebut penelitian deskriptif (descriptive research) adalah "metodologi penelitian yang digunakan untuk meneliti pada suatu kondisi obejek alamiah (Sugiyono, 2005:90).

Subjek dalam penelitian adalah sesuatu yang dijadikan responden dalam penelitian. Subjek penelitian ini adalah peserta didik Hambatan Fisik dan Motorik X yang berada di kelas V SDN X Kecamatan Pauh. Dengan demikian sumber data utama penelitian yang bersifat deskriptif kualitatif ini adalah semua yang terkait kedalam pembelajaran pendidikan jasmani olahraga dan kesehatan di kelas V bagi anak Hambatan Fisik dan Motorik X serta guru bidang studi terkait.

Berdasarkan jenis penelitian dan subjek penelitian yang telah ditetapkan, maka menurut Sugiyono (2014: 224-225) teknik pengumpulan data merupakan langkah yang paling strategis pada penelitian yang akan dilakukan, akan ada data yang perlu untuk dikumpulkan yang disesuaikan dengan kebutuhan penelitian dan untuk menjawab pertanyaan yang ada pada penelitian.

Pengumpulan data dilakukan langsung oleh peneliti sendiri secara langsung kelapangan untuk mendapatkan data yang digunakan dalam penelitian ini meliputi : Kegiatan observasi ini dilaksanakan dalam rangka melihat keadaan proses pelaksanaan pembelajaran pendidikan jasmani adaptif di SD, sehingga adanya kesinambungan antara pembelajaran yang dilakukan pada saat teori dengan keadaan lingkungan yang sebenarnya. Dalam mendapatkan data ini penulis melakukan wawancara dengan guru bidang studi olahraga sehubungan dengan segala sesuatu pelaksanaan pembelajaran meliputi diantaranya metode apa yang digunakan guru dalam mengajar serta metode yang paling disenangi peserta didik dalam belajar. Dokumentasi ini berupa rekaman yang diambil pada saat melakukan studi pendahuluan berlangsung.

Untuk menguji kebenaran atau keabsahan data, dapat dilakukan dengan cara-cara sebagai berikut: Perpanjangan keikutsertaan peneliti itu sendiri sangat menentukan dalam pengumpulan data. Keikutsertaan ini memerlukan perpanjangan keikutsertaan peneliti pada latar penelitian. Ketekunan pengamatan bertujuan menemukan proses pelaksanaan pembelajaran pendidikan jasmani olahraga dan kesehatan bagi anak hambatan fisik dan motorik kelas V di SDN X Kecamatan Pauh. Audit dengan dosen pembimbing bertujuan untuk memeriksa kelengkapan dan ketelitian yang dilakukan sehingga timbul keyakinan bahwa sesuatu yang dilaporkan tentang pelaksanaan pembelajaran Penjas tepat mencapai kebenaran yang diharapkan. Trianggulasi dilakukan untuk mengecek keabsahan data dengan memanfaatkan sesuatu yang lain diluar data, dengan demikian trianggulasi dimaksudkan membandingkan hasil observasi dengan hasil wawncara yang dilakukan pada pembelajaran Penjas. Pemeriksaan teman sejawat melalui diskusi dilakukan agar tidak terjadi penafsiran yang jauh berbeda antara peneliti dengan teman sejawat yang memiliki wawasan yang sama tentang masalah penelitian.

\section{Hasil Penelitian}


SDN X Kecamatan Pauh merupakan salah satu Sekolah Dasar yang terletak di Limau Manis Kecamatan Pauh Kota Padang. Sekolah ini termasuk sekolah penyelenggara pendidikan inklusif. Sekolah ini menerima siswa berkebutuhan khusus yang saat ini sudah duduk di bangku kelas V. Siswa ini mengalami hambatan fisik dan motorik sejak dari lahirnya. Meski mengalami hambatan dalam segi fisiknya siswa $\mathrm{X}$ adalah siswa juara di kelasnya.

Peneliti memilih sekolah ini sebagai tempat penelitian dikarenakan sekolah ini adalah sekolah penyelenggara pendidikan inklusif dan memilki seorang siswa hambatan fisik dan motorik yang juara kelas namun dalam hal ini penulis ingin mengetahui bagaimana pelaksanaan pembelajaran pendidikan jasmani adaptif bagi siswa hambatan fisik dan motorik $\mathrm{X}$ ini.

Dalam mendeskripsikan hasil penelitian ini, peneliti mengambil data meliputi observasi, wawancara, studi dokumentasi. Berdasarkan kisi- kisi yang telah dirancang hasil penelitian pun dideskripsikan sebagai berikut:

A. Perencanaan pembelajaran pendidikan jasmani olahraga dan kesehatan bagi siswa hambatan fisik dan motorik X di SDN X Kec Pauh.

Perencanaan pembelajaran pendidikan jasmani olahraga dan kesehatan bagi anak hambatan fisik dan motorik kelas V dalam penelitian ini meliputi : penyusunan program, kesiapan guru, kesiapan siswa.

1. Penyusunan program pembelajaran bagi siswa hambatan fisik dan motorik.

Berdasarkan hasil penelitian dalam hal perencanaan pembelajaran pendidikan jasmani adaptif bagi anak hambatan fisik dan motorik X pelaksanaanya yakni pada pukul 10:00 WIB pembelajaran telah dimulai. Pada saat penelitian ini berlangsung penulis meneliti pelaksanaan pembelajaran pendidikan jasmani adaptif yang berlangsung satu kali seminggu sesuai dengan catatan wawancara satu.

Dalam hal perencanaan pembelajaran ini Bapak Z selaku guru bidang studi telah membuat serta menyusun terlebih dahulu program pembelajaran seperti RPP dan silabus hanya saja dalam hal perencanaan ini bersifat klasikal berlaku untuk semua siswa tanpa adanya perbedaaan termasuk didalamnya siswa hambatan fisik dan motorik $\mathrm{X}$ yang berada di kelas V.

2. Kesiapan guru dan Kesiapan siswa

Saat mengikuti pembelajaran Penjas yang dilaksanakan setiap hari rabunya cara Bapak Z selaku guru mempersiapkan diri adalah dengan belajar kembali di rumah sebelum mengajar besok pagi seperti melhat kembali RPP yang telah dibuat sebelumnya. Terkhusus untuk $\mathrm{X}$ baiasanya Bapak $\mathrm{Z}$ mencoba mencari informasi melalui beberapa media elektronik dan mencoba mencarikan olahrag yang sesuai dengan kemampuan X.

B. Pelaksanaan pembelajaran pendidikan jasmani olahraga dan kesehatan bagi siswa hambatan fisik dan motorik X.

1. Kegiatan Awal

Pada dasarnya kegiatan awal yang perlu dilakukan guru sebelum dimulainya Proses Belajar Mengajar mencakup salam, do'a, absensi, apersepsi, serta penyampaian tujuan pembelajaran. Hal ini bertujuan untuk menyiapkan peserta didik untuk belajar serta memberikan motivasi bagi siswa.Selain itu, dalam kegiatan pembukaan ini guru juga dapat melihat kesiapan siswa untuk belajar. Penyampaian tujuan pembelajaran kepada peserta didik disampaikan sesekali jika pokok bahasan baru. Namun jika pokok bahasannya merupakan lanjutan atau ulangan dari materi sebelumnya, maka biasanya jarang disampaikan lebih detail lagi.

Proses belajar mengajar akan berlangsung dengan baik ada beberapa faktor yang akan mempengaruhi salah satunya adalah kesiapan seorang guru dan siswa guru harus memilki kemampuan untuk mengontrol siswanya dengan tidak mengabaikan nilai-ilai yang ada.

2. Kegiatan inti pembelajaran

Kegiatan pembelajaran dilakukan sesuai dengan rancangan pembelajaran yang telah disusun sebelumnya. Dalam hal ini seperti jika guru yang bersangkutan menyusun berdasarkan perjam dan sebagainya maka dalam pelaksanaanya juga seperti itu.

3. Kegiatan Penutup

Kegiatan yang biasanya dilakukan saat penutup pembelajaran dilakukan pelemasan atau yang disebut juga pendinginan serta memberikan nasehat serta motivasi kepada siswa untuk dapat memahami cara berolahraga tanpa mengalami cedera. Sedangkan untuk kesimpulan materi biasanya digantikan dengan tanya jawab bersama siswa serta memberikan permainan tradisional yang kiranya dapat membantu siswa dalam mengingat pelajaran yang telah diberikan. Hal ini berkenaan dan bersangkutan erat dengan kegiatan penilaian yang dilakukan guru terhadap penguasaan materi pelajaran yang bersangkutan.

C. Penilaian hasil/ Evaluasi 
Penilaian dilakukan tidak hanya untuk mengungkap hasil belajar ranah kognitif tetapi juga mengungkap hasil belajar ranah afektif dan psikomotor. Selain itu penilaian yang dilakukan harus memiliki azas keadilan yang tinggi. Maksudnya, peserta didik diperlakukan sama sehingga tidak merugikan salah satu atau sekelompok peserta didik yang dinilai. Dalam hal evaluasi ini guru melkaukan evaluasi dari beberapa aspek baik itu tes tulis dan prakteknya sehingga kegiatan penilaian ini lebih akurat.

\section{Pembahasan}

Hasil penelitian ini dibahas berdasarkan kajian teori, sehingga akan nampak bagaimana keterkaitan teori dengan pelaksanaan pembelajaran Pendidikan Jasmani adaptif bagi anak Hambata Fisik dan Motorik X kelas V yang ada di lapangan. Adapun pembahasannya adalah sebagai berikut:

Menurut Samsudin (2008: 2) pendidikan jasmani adalah suatu proses pembelajaran melalui aktifitas jasmani yang di desain untuk meningkatkan kebugaran jasmani, mengembangkan keterampilan motorik, pengetahuan dan perilaku hidup sehat dan aktif, sikap sportif dan kecerdasan emosi.

Anak Hambatan Fisik dan Motorik merupakan anak Menurut Buku Pedoman Pendidikan Inklusif Direktorat PLB, (dalam Bilqis 2012:2) tunadaksa adalah anak yang mengalami kelainan atau cacat menetap pada alat gerak (tulang, sendi, otot) sedemikian rupa sehingga memerlukan pelayanan pendidikan khusus untuk mencapai kemampuan yang optimal.

Berkaitan dengan pelaksanaan pembelajaran pendidikan jasmani adaptif di SDN X Kecamatan Pauh. Sesuai dengan hasil wawancara dan observasi yang dilakukan dalam perencanaan pembelajaran sudah dilaksanakan sesuai dengan perencanaan hanya saja tidak adaya perencanaan khusus yang dibuatkan untuk anak hambatan fiisk dan motorik X. , hal ini berlandaskan dengan yang dikemukakan oleh Dini ( 2013 : 53) yang meliputi: memerhatikan perbedaan individu masingmasing pesera didik, rencana pelaksanaan pembelajaran disusun dengan memperhatikan perbedaan jenis kelamin, kemampuan awal, tingkat inteektual, minat, motivasi belajar, kebutuhan khusus lingkungan peserta didik dan lain sebaginya. Karena hal ini lah yang mendasari peneliti masih kurang sesuainya dalam perencanaan di SDN X Kecamatan Pauh.

Dalam perencanaan pembelajaran salah satunya ada RPP ynag perlu dipersiapkan oleh guru kita membahas mengenai apa saja komponen dari RPP terlebih dahulu kita mengenal mengenai beberapa bentuk perencanaan pembelajaran pendidikan jasmani menurut Rahayu (2013 : 68) yaitunya kalender pendidikan, program tahunan, program semester, silabus, RPP, serta yang terakhir kriteria kelulusan minimal (KKM). Keterampilan manajemen kelas merupakan hal yang penting dalam pengajaran yang baik. Teknik manajemen kelas harus diupayakan agar tidak menganggu aspek pembelajaran dalam pelajaran. Manajemen pembelajaran pendidikan jasmani olahraga dan kesehatan yang efektif akan dapat terwujud dengan melaksanakan langkah-langkah sebagai berikut:

1) Menetapkan aturan kelas.

2) Memulai kegiatan tepat waktu.

3) Mengatur pelajaran.

4) Mengelompokkan siswa.

5) Memanfaatkan ruangan dan peralatan.

6) Mengakhiri pelajaran

Meski demikian tidak adanya perencanaan khusus yang dibuatkan untuk anak Hambatan Fisik dan Motorik X namun siswa ini selalu diikutkan dalam pembelajaran namun ada beberapa kegiatan pelaksanaan yang dimodifikasi bagi anak X ini. Dalam hal pelaksanaan pembelajaram pendidikan jasmani adaptif ada beberapa prinsip yang harus dipenuhi agar pelaksanaan ini dapat berjalan dengan baik dilapangan peneliti menemui adanya modifikasi terhadap praktek di lapangan bagi siswa X yang dilakukan oleh guru. Seperti pelaksanaan pembelajaran yang dimodifikasi pada saat pembelajaran gerak berlari namun $\mathrm{X}$ tidak memilki kemampuan untuk hal tersebut maka ada perbedaan kegiatan yang akan diberikan kepadanya.

Hal yang sama juga berlaku untuk kegaiatan evaluasi dimana evaluasi menurut Harahap (dalam Aziz, 2008 : 72 ) evalusai adalah bertujuan untuk menilai keseluruhan pribadi sang anak dalam sebuah situasi pendidikan yang dialami. Evaluasi yang dilakukan di lapangan yang peneliti temukan adalah dengan cara evaluais tulis dan evaluasi secara praktek yang akan nampak perbedaannya adalah dalam praktek bagi siswa hambatan fiisk motorik X sesuai yang diungkapkan oleh Aziz, (2008 : 75) di mana evalusi memberikan petunjuk tentang ranah-ranah mana yang diperlukan untk diukur. Ketika seorang guru telah memahami kedalaman dari program pendidikan jasmani secara menyeluruh maka guru tersebut harus mengikuti langkah-langkah seperti yang diungkapkan oleh Aziz (2008 : 91) sebagai berikut :

1) Sebagai akhir dari suatu kegiatan

Evaluasi merupakan akhir dari suatu kegiatan, akan mempertimbangkan keterbatasan dalam pelaksanaan evaluasi tersebut, di mana pemborosan waktu akan menggangu proses pendidikan secara keseluruhan. Seorang guru olahraga untuk melakukan evaluasi terhadap kesegaran jasmani siswa maka akan lebih bermanfaat bila tugas yang akan diberikan juga tentang pendidikan jasmani. 
2) Berhubungan dengan kegiatan

Bila bermaksud mengukur tingkah laku sebagai hasil dari pendidikan jasmani maka biasanya akan didapat keteranganketerangan lain tentang pendidikan secar umum. Contoh yang lebih konkrit adalah bila tujuan umum memberikan aktifitas pada kemampuan neuromuskuler maka secara khusus sebenarnya guru juga akan menyiapkan tujuan mengukur tingkah laku yang diperagakan oleh siswa pada saat diberikan perlakukan untuk melihat kemampuan tersebut.

3) Menentukan kebutuhan

Suatu keharusan dalam pengukuran adalah menetukan kebutuhan- kebutuhan individu atau kelompok. Dalam hal ini guru harus mempersiapkan kebutuha masing-masing siswa baik secara individi mapun kelompok itu sendiri.

4) Penentuan nilai terhadap perlengkapan dan metode

Proses evaluasi dalam program pendidikan jasmani seorang guru harus memnerikan pelayanan yang baik pada siswa. baik itu metode maupun perlengkapan yang dapat dipakai berulang-ulang.

5) Pertimbangan untuk keseluruhan individu dengan lingkungan

Data yang akan diinterpretasikan dari hasil pengukuran dan evaluasi harus memperhatikan hubungan keselruhan individu terhadap lingkungan sekitarnya. Secara jelas hasil yang diperoleh terjadi perubahan mendasar dari keseluruhan mendasar dari keseluruhan penampilan mendasar sepanajang semester. Oleh sebab itu guru harus harus memperhatikan keselruhan individu denga lingkunganya, baik sosial ekonomi, umur, jenis kelamin, motivasi dan faktor lainya.

\section{Kesimpulan}

Berdasarkan uraian dan penjelasan dari sebelumnya mengenai pelaksanaan pembelajaran pendidikan jasmani adaptif bagi anak hambatan fisik dan motorik X dapat diambil kesimpulan sebagai berikut : Siswa hambatan fisik dan motorik X yang berada di SDN X Kec Pauh dalam segi perencanaan pembelajaran tidak hal khusus yang diberikan kepada X. X disamaratakan dengan siswa- siswa lainya karena guru berpandangan bahwa $\mathrm{X}$ adalah anak yang pintar yang menjadi pembeda X memilki kekurangan dalam segi fisiknya. Hal tersebut tidak berpengaruh terhadap kemampuan akademik lainya $\mathrm{X}$ adalah juara dikelas dengan perlakukan sistem penilaian yang sama dengan siswa lainya. Titik beda antara $\mathrm{X}$ dengan yang lainya terlihat pada saat pembelajaran olahraga dalam segi praktek berlangsung X pada saat kegiatan awal pemanasan X melakukan pemanasan dengan semangat semampunya saja. Ketika kegiatan inti berlangsung pembelajaran bermain tardisional contohnya $\mathrm{X}$ bapak $\mathrm{Z}$ akan menyampaiakan teori terlebih dahulu kepada seluruh siswanya. Ketika $\mathrm{X}$ tidak memungkinkan untuk diikutsertakan dalam kegiatan tersebut maka bapak $\mathrm{Z}$ akan melakukan modifikasi terhadap kegiatan tersebut sesuai dengan kemampuan X.

\section{Daftar Rujukan}

Arikunto, Suharsimi. (2006). Manajemen Penelitian. Jakarta: PT. Rineka Cipta

Aziz, Ishak. (2008). Tes Pengukuran dan Evaluasi Pembelajaran Olahraga. Padang: FIK UNP

Bilqis. (2012). Lebih Dekat Dengan Anak Tunadaksa. Yogyakarta: Familia. Karyana, Asep ＆～Widiati, Sri. (2013). Pendidikan Anak Berkebutuhan Khusus. Jakarta: PT Luxima Metri Media.

Hosni, I. (2010) Modifikasi Pembelajaran Dalam Pendidikan Jasmani Adaptif. Bandung: UPI Bandung

Rahayu, Ega Trisna. (2013). Strategi Pembelajaran Pendidikan Jasmani. Bandung: Alfabeta

Rosdiani, Dini. (2013). Model Pembelajaran Langsung Dalam Pendidikan Jasmani dan Kesehatan. Bandung: Alfabeta

Rosdiani, Dini. (2013). Dinamika Olahrag dan Pengembangan Nilai. Bandung: Alfabeta

Samsudin. (2008). Pembelajaran Pendidikan Jasmani Olahraga dan Kesehatan. Jakarta: PT. Fajar Interpratama

Sugiyono, P. (2005). Memahami Penelitian Kualitatif. Bandung: Alfabeta.

Suharsimi, A. (2006). Prosedur Penelitian Suatu Pendekatan Praktik. Jakarta: Rineka Cipta.

Tarigan, B. (2000). Pendidikan Jasmani Adaptif. Departemen Pendidikan Nasional Dasar dan Menengah. Jakarta.

Tarigan, B. (2008). Modul Pendidikan Jasmani Adaptif. Bandung: Fakultas Pendidikan Olahraga Dan Kesehatan Universitas Pendidikan Indonesia. 
Taufan, J., \& Mazhud, F. (2016). Kebijakan-kebijakan Kepala Sekolah Dalam Penyelenggaraan Pendidikan Inklusif Di Sekolah X Kota Jambi. Jurnal Penelitian Pendidikan, 14(1). 